\title{
Recently Discovered Hebrew Inscriptions
}

\author{
By A. R. MiLLARd
}

The Early Hebrew texts known before 1950 have been collected and discussed in the works of Diringer and Moscati. ${ }^{1}$ Since the publication of Moscati's corpus a number of inscriptions have come to light as the result of excavation and of chance discovery. Although there are few which contain more than half a dozen words, they have some significance for Old Testament studies. It may therefore be useful to make a brief survey of them in conjunction with those already known. All the ones we shall consider date from the last century of the kingdom of Israel and the ensuing years of the state of Judah. There have been press reports of earlier texts from Arad, near Masada, but no details have yet been announced. ${ }^{2}$

Before turning to the early Hebrew texts, we should notice a group of three bronze arrowheads found near Bethlehem. They have the owner's name engraved upon them in early 'phoenician' letters: $h s$ ' $b d l b$ ' $t$, 'arrowhead of 'Abd-leba'at'. The type of arrowhead and the form of the characters point to a date in the twelfth century B.c. ${ }^{3}$ These, then, are examples of Canaanite writing from the time of the Judges, from the days when Gideon made a boy at Succoth write out a list of the elders of the city for him (Jdg. viii. I4).

The finest specimens of Hebrew writing are naturally those which may be supposed to have emanated from the royal chancelleries in Jerusalem and Samaria. The text from the Siloam tunnel is rightly the most renowned of these and its script clearly shows the transference of the cursive hand to stone. The wealthy Judaeans who could afford the construction of tombs in the rock of the Siloam valley may well have used the skills of the royal scribes in the composition and engraving of their epitaphs. Remains of three of these have been found. Two are merely fragments. 4 The third has been

I. D. Diringer, Le iscrizioni antico-ebraiche palestinesi, Florence, 1934. S. Moscati, L'epigrafia ebraica antica, 1935-1950, Rome, 1951. All texts mentioned without references are to be found in these two books.

2. The Jewish Chronicle I5. vi. 62.

3. J. T. Milik and F. M. Cross, BASOR ${ }_{134}$ (1954), pp. 5-15. For similar arrowheads with Phoenician inscriptions, v. J. T. Milik, Bulletin du Musée de Beyrouth XVI (1961), pp. 103-108.

4. A. Reifenberg, JPOS XXI (1948), pp. 134-137; N. Avigad, IEJ V (1955), p. 163 . 
brilliantly reconstructed by N. Avigad. ${ }^{5}$ The wording is simple, comparable with later tomb inscriptions. There is no need to repeat here the details of its possible connection with Is. xxii. I5-16.6 The forms of the letters in these inscriptions differ only slightly from those of the Tunnel text and all are of approximately the same date, late in the eighth century B.c. Apart from these there are no surviving examples of the work of the royal scribes of Jerusalem. Yet I would like to suggest that further evidence of their work has been found at Samaria. In one room of the Israelite palace there were fragments of at least fifty clay sealings, bearing on the reverse the imprint of fibres of the papyrus sheets to which they were once attached. ${ }^{7}$ Nine of the bullae are stamped with the device of a four-winged beetle. This resembles closely the design found impressed upon many jar handles in Judah and has been recognised by Professor Y. Yadin as the royal emblem of the Southern Kingdom. ${ }^{8}$ It would be futile to indulge in long speculation upon the content of these vanished documents but it does seem possible that they included letters from the kings of Judah, dispatched under the royal seal.

Samaria has yielded only one tantalising fragment of a monumental inscription, bearing, apparently, the word 'which'. 9 However, this lack may be partially infilled by the text on a fragmentary ivory plaque found at Nimrud in northern Iraq. ${ }^{10}$ Unfortunately only two consecutive words remain on this. The traces indicate that it was part of a dedicatory inscription affixed to a larger object and ending, perhaps, with a curse; the legible words are 'from a great king' and 'and they wiped out, will wipe out' (mmlk.gdl, wmhw). The form of script is close to the Siloam texts and also has connections with the Samaria ostraca. It is a cursive hand but very carefully and neatly engraved. There can be little doubt that it is a Hebrew inscription. Sargon of Assyria's sack of Samaria in $72 \mathrm{I}$ B.c. provides a likely date for its transportation to the storehouses of Nimrud.

5. IEJ III (1953), pp. 137-I $5^{2}$.

6. Cf. D. J. Wiseman, Illustrations from Biblical Archaeology, London, 1956, p. 59 .

7. J. W. and G. M. Crowfoot and K. M. Kenyon, Samaria-Sebaste III, London, 1957, pp. 2, 88.

8. Scripta Hierosolymitana VIII, Jerusalem, I96 I, pp. I3, I4.

9. Samaria-Sebaste III, pp. 33-34, Pl. IV. I.

Io. A. R. Millard, Iraq XXIV. I (1962), pp. 45-49, Pl. XXIV. a. 
Routine scribal duties are exemplified by the ostraca from Samaria recording deliveries of oil, grain and wine, possibly from the royal estates. ${ }^{11}$ The two from Tell Qasile show that this was a common method of recording, one of these is a receipt for gold of Ophir. The normal practice was to write on papyrus or skin. For that reason the most important recent discovery is the rather miserable manuscript from a cave in the wadi Murabba'at, near the Dead Sea. ${ }^{12}$ The sheet of papyrus was used four times. The first two texts are lost; there remains sufficient of the third to tell that it was a letter. The beginning, unless a part is missing, differs from that of other Hebrew letters, 'Says X to you .... It is more like the formula found in Babylonian letters of the second millennium. A list of names was later written over the letter. The cursive script was dated by M. Milik to the middle of the eighth century B.c. F. M. Cross has given it a lower date, in the first half of the seventh century, after meticulous study of the writing. ${ }^{13}$ Beside the names in the list are amounts of grain, maybe in seah. The numerals are of some interest as they lead Milik to a re-interpretation of the figures on the Samaria ostraca, the figures which have been used to provide a date for these documents. The result, a date in the reign of Joash (c. 798-782/1 B.c.) is about half a century earlier than that recently reached by Professor Yadin in a study of the numerical system. ${ }^{14} \mathrm{He}$ places them in the reign of Menahem (c. $75^{2}-742 / \mathrm{I}$ B.C.), a time more in agreement with the evidence of the archaeologists, and this has been accepted by Cross. ${ }^{15}$ The systems of numerical signs proposed by both Milik and Yadin seem to have some weaknesses. The material available cannot provide a definite result. It is noteworthy, however, that a more complicated system was in use among Hebrews than among the Aramaeans of the Phoenicians. Each had a single horizontal bar for ten, two for twenty, three for thirty, although they are not always arranged in the same way. For one, two and three each shows vertical strokes and these are continued up to nine in Aramaic

I I. Their purpose has recently been reconsidered by Y. Yadin, IEF IX (1959), pp. $184-187$.

12. J. T. Milik in R. de Vaux, Discoveries in the Fudaean Desert II, Oxford, 1961, pp. 93-I00, Pl. XXVIII.

13. BASOR I65 (1962), pp. 34-42.

14. Scripta Hierosolymitana VIII, pp. I 7-25.

15. Loc. cit. p. 35 . 
and Phoenician, often in groups of three. ${ }^{16}$ Hebrew texts have special signs for four and five, according to Milik, and for four, five and eight, according to Yadin. In Yadin's system nine is written as four plus five. Whatever the exact value of the various signs may be, it is clear that Hebrew scribes were accustomed to the use of figures to such an extent that they had special ciphers where the neighbouring peoples had the clumsy method of writing in units.

The number of jar handles bearing the impression of a royal seal inscribed 'belonging to the king' and the name of one of four places (Hebron, Memšat, Succoh and Ziph) has been increased, notably by the excavations at Ramat Rahel. No-one has yet shown conclusively just what purpose the stamps served. The presence of a private seal impression on the same handle as a royal one at Ramat Rahel demands that the handles carrying only private stamps be considered together with the royal jars-unless this one example is only a mistake of the official who sealed them. ${ }^{17}$ The Royal stamps have a device in the centre, either the four-winged beetle or an unidentified emblem, the 'flying scroll'. Thus they could be easily recognised even if all the writing was obliterated. On many examples the place-name is quite illegible as a result of a poor impression. Therefore no great importance could have been placed upon the particular town, the stamp indicated some form of royal control. If the private stamps were to serve any purpose they would require the attention of someone who could at least read the letters, whether at an issuing point or at a receiving depot. The same requirement is inherent in the inscribed jar handles from el-Jib (Gibeon, sixth century B.c.). They have a personal name and the place name Gibeon scratched upon them. There must have been a man who could read and check these jars, assigning them according to their owners. Perhaps he sat at the gateway to the yard wherein the wine was stored. 18

16. Two Aramaic notes on Assyrian tablets have a sign for five the same, according to Milik, as one of the Hebrew signs. Yadin (loc. cit. p. 19, n. 56) tries to show that the signs are not similar. Collation of one of the originals in the British Museum tends to support Milik, (K. 76; L. Delaporte, Epigraphes Araméenes, Paris, 1912, p. 34 , No. 14. The second example, K. $28 \mathrm{r}$; ibid, p. 32, No. 12 is illegible). The sign is closer to the Samaria form than Yadin suggests.

17. Y. Aharoni, Excavations at Ramat Rahel, 1959 and 1960, Rome, 1962, p. i6؛ pp. $5 \mathrm{I}^{\mathrm{I}-56}$ for discussion, with which $c f$. Y. Yadin, BASOR $\mathrm{I} 63$ (I96I), pp. 6-1 2 and P. Lapp, BASOR I 58 (1960), pp. I I-22.

18. J. B. Pritchard, Hebrew Inscriptions and Stamps from Gibeon, Philadelphia, 1959; $B A S O R$ I6o ( $196 \mathrm{I})$, pp. 2-6. Details of the industrial area are reported in Vetus Testamentum, Supplement VII, 1960, pp. I-12; BA XXIII, (1960), pp. 23-29; Illustrated London News 10 :ix: 1960 , pp. 433-435. 
The number of inscribed seal-stones also continues to increase. About one hundred and seventy are now known, a considerable number in relation to the size of the kingdoms of Israel and Judah. Although they are not all contemporary, yet there are far more than the Aramaic or Phoenician seals which have been found. This cannot be entirely due to the concentration of study and excavation in Palestine for most of them have been found by chance. The excavations at Lachish produced the largest group, six stones and five impressions. ${ }^{19}$ In contrast the three years of work at Shechem have resulted in one, ${ }^{20}$ none were found at Hazor. Miss Kenyon, in the latest season at Jerusalem, is reported to have found two. There is one stone and two impressions from the excavations at Samaria. ${ }^{21}$ All of those which can be reasonably dated are of the eighth century or later. ${ }^{22}$ One, the famous seal of Shema, servant of Jeroboam, from Megiddo has recently been re-attributed to the reign of the first Jeroboam in the tenth century on epigraphic grounds. ${ }^{23}$

A few ink inscribed ostraca have been found during the last ten years. They were the least important form of document, being notes or copies of others. There is a small fragment bearing two Canaanite letters of the thirteenth century B.C. ${ }^{24}$ and another short text from Hazor. ${ }^{25}$ Much longer is the letter found at Mezad Hashavyahu. It seems to have been written by an inexperienced scribe, the letter aleph is written backwards. In this the sender demands the return of a cloak which he claims has been wrongly taken from him. ${ }^{26}$ The legal and social implications of this document are subjects for further study. ${ }^{27}$ Two other texts from this site are yet unpublished.

19. O. Tufnell, Lachish III, London, I956, pp. 347-8.

20. J. F. Ross and L. E. Toombs, Archaeologv XIV (I96r), p. I 76 an amethyst inscribed $l m b n$.

21. Samaria-Sebaste III, pp. 2 1, 87-88, nos. 2 I, 39, $4^{0 .}$

22. S. Moscati, op. cit., Chapter V

23. S. Yeivin, 7 NES XIX (1960), pp. 205-212. Two seals of Phoenician style have been discussed by $\mathrm{R}$. Giveon, $P E Q 93$ (196I), pp. 38-42.

24. Y. Yadin, Hazor I, Jerusalem, I958, PI. CLX. 2, BA XIX (I956), p. II.

25. Y. Yadin, Hazor II, Jerusalem, I96o, p. 73, no. 6.

26. J. Naveh, IEJ X (196o), pp. I 29-1 39. Cf. the study by F. M. Cross, BASOR I 65 , pp. $4^{2-46}$, embodying certain observations by W. F. Albright.

27. S. Yeivin, Bibliotheca Orientalis XIX (1962), pp. I-10. 
Other minor documents are scratched upon potsherds. Most of these graffiti are simply personal notes. ${ }^{28}$ One jar from Hazor belonged to a man named Peqah, perhaps the Israelite king, but not necessarily, and contained a substance called $s m d r .29$ If this word has been correctly read-there are other opinions-it provides an extra-Biblical occurrence of a word known only in the Song of Songs (ii. I3, I5; vii. I3; semadar) where AV has 'tender grapes'. Professor Yadin has suggested that it was a drink made from the blossom or sap of the vine before the grapes were ripe. The same word has now been found on two Assyrian tablets from Nimrud. ${ }^{30}$ These are dockets originally fastened by a string to a jar or container and describing the content and the owner. One states: 'Oil of samadir, woman Mar-idi, 2 Ist of Ayar' 724 B.C.; the other: 'Oils of samadir resin belonging to the woman Ahuya.' Oils distilled from resins or gums were commonly employed in medical treatment as well as in toilet preparations. From this we may surmise that semadar was an exudation from the vine which was used as ointment or perfume, rather than a drink. Such a meaning would also be suitable in the context of the Song.

All these texts, both the long-known ones and the more recent discoveries are evidence of the practice of writing in the Jewish kingdoms. Of course, no-one now denies the presence of scribes in the capital cities, attached to the courts of the kings. The graffiti, personal names and various odd notes found at the site of almost every excavated town attest a wider knowledge of scribal skills. Some of them are poorly or carelessly written. Such may be the work of local scribes. But the names scratched upon household vessels are unlikely to have been written by any other than the owners of these vessels. This presupposes an even wider knowledge or writing, even if it was only a familiarity with the letters of the alphabet. Widespread knowledge of writing certainly allows for the possibility of the recording of long, literary compositions and

28. A large jar of the 7 th-6th centuries B.c. from Azor is inscribed lslmy "belonging to Shalmay', M. Dothan, Atiqot III (I96I), pp. I8I-I84, Pl. XXVIII. 4, 5. An eighth century vessel from Ein Gev on the eastern bank of Galilee bears the inscription $l^{\prime} q y^{\prime}, I E \mathcal{X}$ XI ( $196 \mathrm{I}$ ), p. I 93. A fragment from Shechem has two letters, (eighth century), $B A \times X$ (1957), pp. 98, 99, fig. 10. There are several from Hazor, Y. Yadin, Hazor II, pp. 70-75, Pls. CLXIX-CLXXII; Hazor III-IV, Pls. CCCLVII-CGCLVIII. Two names are noted on a sherd from Ramat

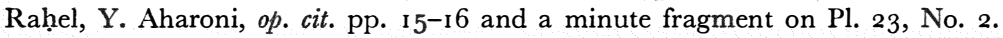

29. Y. Yadin. Hazor II, pp. 73-74, No. 7 .

30. B. H. Parker, Iraq XXIII. I (I96I), pp. 19-20, ND. 2303, 2304. 
makes for a respect of the written word. Since such have not been discovered it should not be argued that they did not exist. ${ }^{31}$

Comparison of the shapes of individual letters of the Hebrew inscriptions reveals a certain uniformity of style. Naturally there are many variations, some the vagaries of individual scribes. When the letters are placed beside western Aramaic inscriptions of the same age there are obvious and considerable differences of style and of form. The same can be observed when the Phoenician letters are compared, although there are very few examples of these. The Hebrew writing appears the more developed, the more elegant. The Siloam tunnel inscription and the ivory plaque from Nimrud, if it did originate in Samaria, are the work of well trained and experienced writers. The competent, flowing script bespeaks the continual exercise of their skills. Israel and Judah may never have been literate as nations, but they were familiar with writing and its possibilities. It can never have been difficult to find 'the pen of the ready scribe'.

31. Cf. J. Gray, Archaeology and the Old Testament World, 1962, pp. 1 76-8; contra D. W. Thomas, $7 S S$ VI. I ( $196 \mathrm{I})$, pp. $33-46$.

The substance of a paper read to the Old Testament Group of the Tyndale Fellowship, July ig62. 